\title{
Bacterial Community and Anti-Cerebrovascular Disease-Related Bacillus Species Isolated from Traditionally Made Kochujang from Different Provinces of Korea
}

\author{
Gwangsu Ha ${ }^{1}$, Hee-Jong Yang ${ }^{1}{ }^{(}$, , Myeong-Seon Ryu ${ }^{1}$, Su-Ji Jeong ${ }^{1}$, Do-Youn Jeong ${ }^{1, *}$ and Sunmin Park ${ }^{2, *}$ \\ 1 Department of R \& D, Microbial Institute for Fermentation Industry, Sunchang-Gun 56000, Korea; \\ ksnova1492@naver.com (G.H.); godfiltss@naver.com (H.-J.Y.); rms6223@naver.com (M.-S.R.); \\ yo217@naver.com (S.-J.J.) \\ 2 Department of Food and Nutrition, Obesity/Diabetes Research Center, Hoseo University, Asan 31499, Korea \\ * Correspondence: jdy2534@korea.kr (D.-Y.J.); smpark@hoseo.edu (S.P.)
}

Citation: Ha, G.; Yang, H.-J.; Ryu, M.-S.; Jeong, S.-J.; Jeong, D.-Y.; Park, S. Bacterial Community and Anti-Cerebrovascular Disease-Related Bacillus Species Isolated from Traditionally Made Kochujang from Different Provinces of Korea. Microorganisms 2021, 9, 2238. https://doi.org/10.3390/ microorganisms 9112238

Academic Editor:

Theodoros Varzakas

Received: 6 October 2021

Accepted: 26 October 2021

Published: 27 October 2021

Publisher's Note: MDPI stays neutral with regard to jurisdictional claims in published maps and institutional affiliations.

Copyright: (c) 2021 by the authors. Licensee MDPI, Basel, Switzerland. This article is an open access article distributed under the terms and conditions of the Creative Commons Attribution (CC BY) license (https:// creativecommons.org/licenses/by/ $4.0 /)$.

\begin{abstract}
Traditionally made Kochujang (TMK) is a long-term fermented soybean and rice mixture with red pepper and salts. The ambient bacteria in rice straw and nutrient components of Kochujang influence the bacteria community. We aimed to investigate the bacterial composition and quality of TMK from different provinces of Korea: Chungcheung (CC), Jeolla (JL), Kyungsang (KS), and GeongGee plus Kangwon (GK) provinces, and Jeju island (JJ). Furthermore, Bacillus spp. isolated from TMK were studied to have anti-cerebrovascular disease activity and probiotic properties. Seventy-three TMK samples from different regions were collected to assess the biogenic amine contents, bacteria composition using next-generation methods, and bacterial functions using Picrust2. Bacillus spp. was isolated from the collected TMK, and their antioxidant, fibrinolytic, and angiotensin I conversion enzyme (ACE) inhibitory activities and probiotic properties were examined. KS TMK had lower sodium contents than the other TMK. There were no significant differences in histamine and tyramine contents among the TMK samples in different provinces. The predominant bacteria in TMK was Bacillus spp., but KS included much less Bacillus spp. and higher Enterococcus and Staphylococcus than the other TMK. Gene expression related to lipopolysaccharide biosynthesis was higher in KS TMK than the other TMK in Picrust2. The predominant Bacillus spp. isolated from TMK was B. subtilis and B. velezensis. B. subtilis SRCM117233, SRCM117245, and SRCM117253 had antioxidant activity, whereas $B$. subtilis had higher fibrinolytic activity than other Bacillus spp. Only B. velezensis SRCM117254, SRCM117311, SRCM117314, and SRCM117318 had over 10\% ACE inhibitory activity. In conclusion, KS had less Bacillus related to lower sodium contents than the other TMK. The specific strains of B. subtilis and B. velezensis had antioxidant, fibrinolytic, and ACE inhibitory activity, and they can be used as a starter culture to produce better quality controlled Kochujang with anti-cerebrovascular disease activities.
\end{abstract}

Keywords: traditionally made Kochujang; Bacillus subtilis; Bacillus velezensis; fibrinolytic activity; angiotensin I conversion enzyme inhibitory activity; antioxidant activity

\section{Introduction}

In Korea, primary seasonings or sauces are based on fermented soybeans, called Jang. Jang comprises chungkookjang, doenjang, Kochujang, and kanjang. Chungkookjang is a short-term (2-3 days) fermented soybean without salts, while the other types of Jang are composed mainly of meju, fermenting cooked soybeans with or without grains for more than two months in a dry and cool condition without salts [1]. Kochujang was used as a medicinal food for promoting digestion in Hyangyak-Jipsongbang in 1433 [2]. Kochujang appeared in the diet components recorded in Siksanjip, published by Lee in the 18th century [3]. There is no similar fermented food to Kochujang using meju and red 
pepper powder in other Asian countries, raw chopped red pepper is added to the crushed, fermented soybeans in other Asian countries.

Unlike doenjang, mainly fermenting cooked soybeans, traditionally made Kochujang (TMK) is made of meju powder, malted glutenous rice powder, and red pepper powder, and the mixture is fermented and aged for over 6 months [4]. TMK contains higher carbohydrate sources than doenjang, and it may have diverse bacteria with high quantities. The isolated Bacillus spp. may have different characteristics in different types of Jang because their fermentation condition and ingredient compositions are different [5]. Functionalities of the Jang depend on the bacteria compositions and their metabolites. However, with natural fermentation it is challenging to control the bacteria community of Jang, and its quality control and functionalities are difficult to maintain. Thus, Jang fermented while inoculating specific bacteria must be examined. For example, chungkookjang fermented while inoculating specific Bacillus spp. has been produced and commercialized. Chungkookjang for managing glucose metabolism has been commercialized in Korea. Chungkookjang, fermented with Bacillus (B.) amyloliquefaciens (SRCM 100730, SRCM 100731, and SCGB 1), has probiotic properties and antidiabetic and anti-stoke activities in animal models $[1,6]$. Thus, TMK made with the inoculation of isolated specific Bacillus spp. may have a specific function. However, a few studies have isolated Bacillus spp. from Kochujang and assessed its functionality. These processes are crucial to make Kochujang with specific functionalities and quality control [7]. Therefore, the predominant and beneficial bacteria in Kochujang need to be isolated and the functionalities identified to make inoculated Kochujang with specific functionality.

Cerebrovascular diseases, mainly ischemic stroke, are globally increasing, associated with hyperglycemia, dyslipidemia, hypertension, and platelet aggregation [8,9]. Kochujang has been reported to control energy, glucose, lipid, and the thrombosis metabolism involved in cerebrovascular diseases in cell-based, experimental animal and human studies [4,10-12]. However, no studies have been conducted for the Bacillus spp. effect from Kochujang for anti-ischemic stroke, although some Bacillus spp. such as B. subtillis natto and other strains have antithrombotic activity $[13,14]$. Bacillus spp. from kocujang may have anti-ischemic stroke activity. Therefore, the bacteria community of traditional Kochujang needs to be analyzed, and beneficial bacteria should be isolated from Kochujang and the functionality examined for anti-ischemic stroke. Specific Bacillus spp. can be used to make an optimal koji inoculate for producing Kochujang with better flavor and functionalities. This study aimed to examine the bacterial community and functions of Kochujang from five different areas of Korea, and various Bacillus strains with inhibitory functions of cerebrovascular diseases and probiotics were isolated from the different Kochujang. The present study is novel to demonstrate that the TMK samples from different areas had different bacteria communities, and they needed better quality control. The Bacillus spp. having anti-cerebrovascular diseases were isolated and characterized. These results are crucial to developing inoculated Kochujang having anti-cerebrovascular diseases.

\section{Materials and Methods}

\subsection{General Production Process of Traditionally Made Kochujang (TMK) and Sample Collection}

TMK is generally made using a two-step fermentation method: (1) the fermentation of a dried brick-shape of steamed soybeans with rice straw at 33-35 ${ }^{\circ} \mathrm{C}$ for $40-50$ days and crushed into powder (meju powder); (2) and the natural fermentation and aging of the mixture of $25 \%$ the degraded starch in glutenous rice powder with malt, 10-13\% red pepper, $57-60 \%$ meju powder, and $5 \%$ salts outside at approximately $20-25{ }^{\circ} \mathrm{C}$ for over 100 days (Figure 1) [4].

The scheme of the study design is shown in Figure 2. TMK samples were collected from local markets in different provinces in Korea, including Jeonbuk (14 samples), Jeonnam (nine samples), Gyungkee (seven samples), Kyungbuk (six samples), Kyungnam (six samples), Kangwon (seven samples), Chungbuk (six samples), and Chungnam (nine samples) provinces, and Jeju island (six samples). Considering the area characteris- 
tics, Jeolla (Jeonbuk + Jeonnam; $n=23$ ), Kyungsang (Kyungbuk + Kyungnam; KS; $n=12$ ), Gyungkang (Gyungkee-Do + Incheon + Kwangwon; GK; $n=17$ ), and Chungcheung provinces (Chungbuk + Chungnam, CC; $n=15)$, and Jeju island $(\mathrm{JJ} ; n=6)$. Seventy-three TMK samples were collected in various areas of Korea in 2019-2020, and the collected TMK samples were stored at $4{ }^{\circ} \mathrm{C}$ until further analysis.

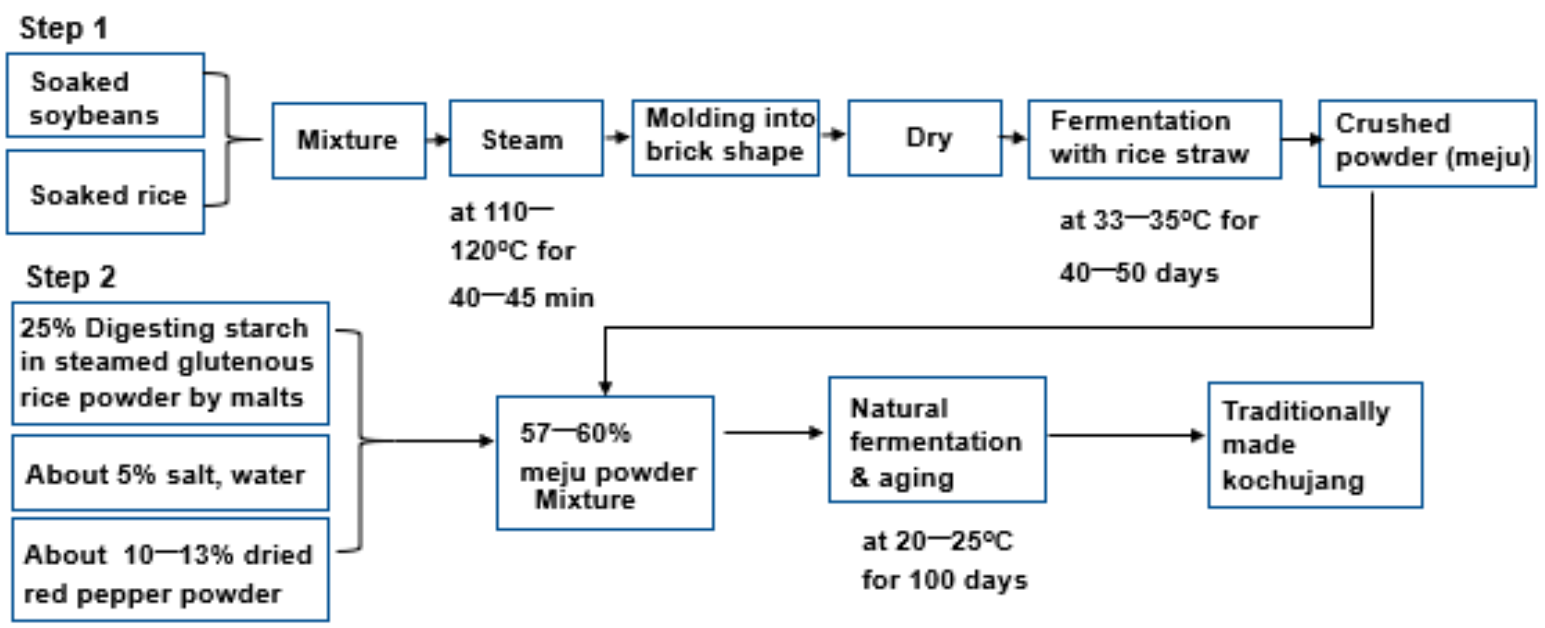

Figure 1. Procedures for traditionally made Kochujang (TMK).

To measure sodium, histamine and tyramine contents in TMK samples
To collect 73 traditionally made Kochujang (TMK) samples 9 provinces in Korea

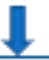

Grouping TMK samples into 5 regions according to the similar environment
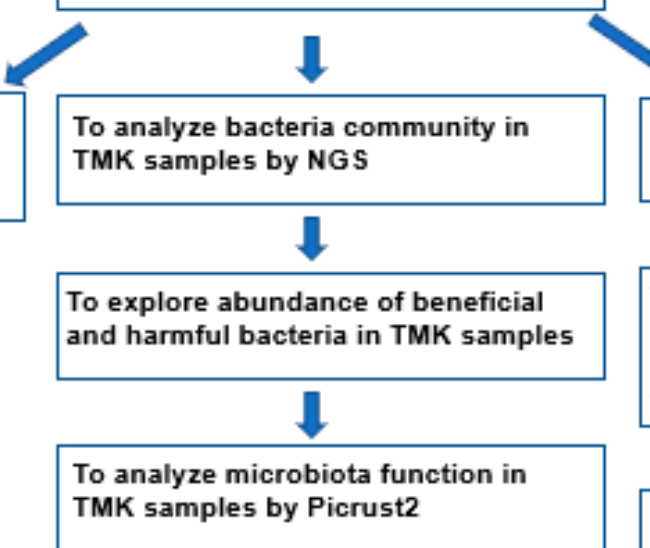

To isolate Bacillus spp. from TMK samples

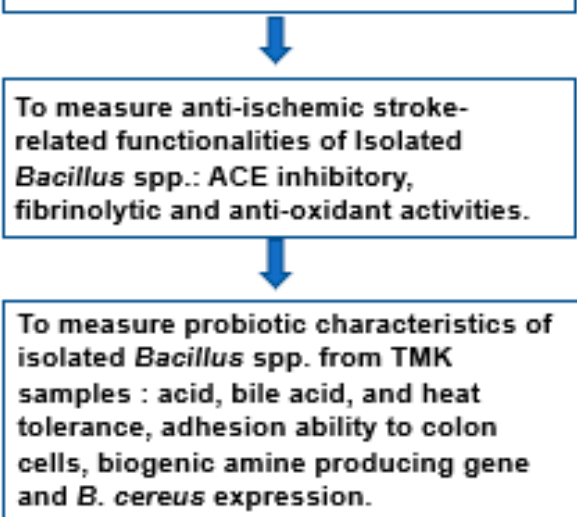

Figure 2. Scheme of the study design.

\subsection{Sodium Contents in TMK Samples}

Sodium contents of TMK samples were measured according to the Korean Food Code method 9.1.2.1.1 and 9.1.2.1.6. As sample preparation for measuring sodium contents, each TMK sample was digested using a microwave digestion system, and the digested TMK 
sample was diluted into deionized water. Sodium contents were measured using ICP-AES (Arcos, Spectro, Kleve, Germany) and ICP-MS (icapQ, Thermo, Waltham, MA, USA) [15].

\subsection{Bacteria Community Analysis of the Collected TMK by the Next-Generation Sequencing (NGS) Method}

The DNA extracted from the $0.2 \mathrm{~g}$ well-mixed TMK samples using the DNeasy PowerSoil Kit (Qiagen, Hilden, Germany) was amplified using 16S amplicon primers targeting V3 and V4 regions in a polymerase chain reaction (PCR). Libraries of the DNA PCR products were prepared according to the GS FLX plus library prep guide. The DNA was amplified with 16S universal primers in the FastStart High Fidelity PCR System (Roche, Basel, Switzerland) described elsewhere [5]. Bacterial DNA sequences in the TMK samples were measured using the Illumina MiSeq standard operating procedure on a Genome Sequencer FLX plus (454 Life Sciences, Branford, CT, USA) in the Microbial Institute for Fermentation Industry (Soon Chang, Korea).

The $16 \mathrm{~S}$ amplicon sequences of each TMK were assessed using Mothur v.1.36. Using the Miseq SOP, the sequences were aligned using the Silva reference alignment v.12350, and the taxonomy and bacteria counts in each TMK were determined [16]. After removing the operational taxonomic units (OTUs) below 10,000 reads, the relative bacteria number of each TMK was calculated in the taxonomic assignments at the family, order, genus, and species levels. Bacteria clustering of the TMK samples from different areas was conducted by a principal component analysis (PCA) using the R package. The $\alpha$-diversity with the Chao and Shannon indices was determined using the Mothur program. The counts of beneficial and harmful bacteria were analyzed in TMK samples of different areas.

\subsection{Microbiota Function of TMK Samples}

The gene functions of bacteria in the TMK samples were predicted by a PICLUST2 pipeline analysis. Among the predicted metabolic characteristics of TMK microbiota, the abundance of the Kyoto Encyclopedia of Genes and Genomes (KEGG) Orthologues was analyzed using the KEGG mapper (https: / / www.genome.jp/kegg/tool/map_pathway1.html (accessed on 11 March 2021)).

\subsection{Isolation and Identification of Bacillus spp.}

Each TMK sample $(1 \mathrm{~g})$ was placed in $9 \mathrm{~mL}$ of sterile distilled water for $30 \mathrm{~min}$ and serially diluted. Each diluted suspension was plated onto a Luria-Bertani (LB) agar (Difco, Sparks, MD, USA), and the inoculated agar plate was incubated at $30{ }^{\circ} \mathrm{C}$ for $24 \mathrm{~h}$ to separate the Bacillus spp. The Bacillus spp. in the LB plate were screened with morphological differences, and the isolates were separated for the second incubation to verify them.

Bacteria colonies were isolated from the LB plate, and their bacterial species were identified after 16S rRNA sequencing with an ABI 310 automated sequencer according to the manufacturers' instructions (Perkin-Elmer, Foster, CA, USA), using the proper PCR primers in Macrogen Inc. (Seoul, Korea) [17]. The PCR product sequence was matched with 16S rRNA gene sequences in the NCBI GenBank database with multiple sequence alignment using the CLUSTAL W program (http:/ / www.clustal.org/clustal2/ (accessed on 30 March 2021)).

\subsection{Adhesion of Isolated Bacillus spp. into the Colon Cells In Vitro}

The adhesion of Bacillus spp. to colon cells was conducted with the previously described method [18]. Briefly, human colon-derived CCD-18Co cells were seeded into 24-well plates at $2 \times 10^{5}$ cells/well and incubated for $24 \mathrm{~h}$. Isolated Bacillus spp. were inoculated to the plate at 10:1 multiplicity of infection (MOI) and incubated at $37{ }^{\circ} \mathrm{C}$ in a $5 \% \mathrm{CO}_{2}$ atmosphere for $45 \mathrm{~min}$. The cells in the wells were washed three times with fresh minimum essential media (MEM) to remove unbound bacteria by aspirating the LB media. The number of remaining bacteria was counted under a microscope, and the percentage of total bacteria added to the plate was calculated [18]. 


\subsection{B. cereus and Biogenic Amine Producing Gene Expression}

B. cereus included cytotoxin $\mathrm{K}$ (CytK), enterotoxin FM (ent FM), enterotoxin $\mathrm{T}$ ( $b c e T$ ), non-hemolytic enterotoxin (nheA), hemolysin BL ( $h b l C)$, and emetic toxin (CER) genes. Their gene expressions were measured in the genomic DNA of the isolated Bacillus spp. by PCR. When their gene expression was positive, the Bacillus was considered as B. cereus positive bacteria. Biogenic amine-producing genes, including histidine decarboxylase $(h d c)$ and tyrosine decarboxylase $(t d c)$, were also measured from the genomic DNA of the isolated Bacillus spp. by PCR. As described previously, the PCR conditions and PCR primers for $C y t K$, nheA, ent FM, bceT, $h b l C, C E R, h d c$, and $t d c$ were provided $[19,20]$. Bacillus spp. with decarboxylase activity was used for the positive control for $h d c$ and $t d c$ expression. Media with no bacteria was considered a negative control. The PCR products were identified by running electrophoresis in $2 \%$ agarose gel. The DNA bands for CytK, nheA, ent FM, bceT, $h b l C, C E R, h d c$, and $t d c$ expression were detected [5].

\subsection{Biogenic Amine Production and Content Measurement}

Biogenic amine production by isolated Bacillus spp. during fermentation was determined as described previously [21]. Isolated Bacillus spp. was cultured in LB liquid media with $1000 \mathrm{ppm}$ of tyrosine (Sigma-Aldrich, St. Louis, MO, USA) and histidine (Sigma-Aldrich) in a shaking incubator at $37{ }^{\circ} \mathrm{C}$ for $24 \mathrm{~h}$. The supernatants were separated at 15,000 rpm for $30 \mathrm{~min}$ after incubation. Standards of histidine and tyramine were made with $0.1-100 \mathrm{mg} / \mathrm{L}$ in a $0.01 \mathrm{~N} \mathrm{HCl}$ solution. The 1,7-diaminoheptane $(0.1 \mathrm{~g} / \mathrm{L}$, Sigma-Aldrich) was added as an internal standard to the samples and standards (1:2, v:v) and mixed with a saturated $\mathrm{Na}_{2} \mathrm{CO}_{3}$ (Sigma-Aldrich) solution and $1 \%$ dansyl chloride (Sigma-Aldrich) to make derivatives.

The culture media or TMK samples were mixed with ethyl ether (Samchun, Seoul, Korea) for $3 \mathrm{~min}$, and the supernatants were separated. After removing the solvent under nitrogen gas, the concentrates were dissolved into acetonitrile (Duksan, Seoul, Korea). The mixed solution was filtered with a $0.45 \mu \mathrm{m}$ syringe filter (Sartorius, Frankfurt, Germany). The contents of biogenic amines in the culture media and TMK were then measured by a high-performance liquid chromatography (HPLC) analysis with a Cepcell Pak C18 column $(2.0 \times 250 \mathrm{~mm})[21]$.

\subsection{Characteristics and Cerebrovascular Disease-Related Functionalities of Isolated Bacillus}

Bacillus spp. excrete the enzymes into the culture media when they produce the enzymes from existing genes. Extracellular enzyme activities, including angiotensin I conversion enzyme (ACE) inhibitory, antioxidant, and fibrinolytic activities, were measured with the culture media [22,23]. Each isolated Bacillus colony from the TMK samples was individually cultured in LB liquid media at $30^{\circ} \mathrm{C}$ for $24 \mathrm{~h}$, and the culture media was separated after centrifuging at $13,000 \mathrm{rpm}$ for $10 \mathrm{~min}$. The antioxidant activity was estimated by the 2,2-diphenyl-1-picryl-hydrazyl (DPPH, Sigma-Aldrich, St. Louis, MO, USA) activity and superoxide dismutase (SOD)-like activity [5,24]. The culture media supernatants were mixed to $100 \mu \mathrm{M}$ DPPH in ethanol (10:1) and incubated in a dark room for $30 \mathrm{~min}$. The color of the mixture was measured at $517 \mathrm{~nm}$ by UV/VIS spectrophotometer (SPECORD200, Analytik Jena, Jena, Germany). DPPH free radical scavenging activity (\%) was calculated with the equation: (1-Absorbance of DPPH solution) $\times 100$. The SOD-like capacity was measured with a SOD kit (Sigma-Aldrich, St. Louis, MO, USA). The culture media supernatants were incubated with a working solution of SOD kit $(10: 1 ; v / v)$ and mixed with a working SOD enzyme solution with the same sample volume. The mixture was incubated at $37^{\circ} \mathrm{C}$ for $20 \mathrm{~min}$, and the optical density was measured at $450 \mathrm{~nm}$.

The fibrinolytic activity of each isolated bacteria was measured using the fibrin plate method [25]. The fibrin plate was composed of dissolving human fibrinogen in a $10 \mathrm{mM}$ sodium phosphate buffer ( $\mathrm{pH} 7.4$ ) to a final concentration of $0.5 \%$, followed by the addition of $100 \mathrm{unit} / \mathrm{mL}$ of thrombin (Sigma-Aldrich, St. Louis, MO, USA) and 1\% agarose (Bio-Rad, Hercules, CA, USA). The culture media was spotted on the middle of the fibrin plate, 
followed by incubation at $37^{\circ} \mathrm{C}$ for $24 \mathrm{~h}$. When the enzymes with fibrinolytic activity exist in isolated Bacillus, they are secreted into the culture, and the fibrin is degraded to make a clear zone. The diameter of the cleared zone was measured [25].

The ACE inhibition activity was measured using the method reported by Ghanbari et al. [26]. The culture media of isolated Bacillus spp. was added to a $0.1 \mathrm{M}$ sodium borate buffer ( $\mathrm{pH}$ 8.3) and $0.5 \mathrm{U} / \mathrm{mL}$ of ACE (Sigma), and the mixture was then cultured at $37^{\circ} \mathrm{C}$ for $10 \mathrm{~min}$. N-Hippuryl-His-Leu hydrate $(5 \mathrm{mM}, \mathrm{HHL}$, Sigma) was added to the mixture and incubated at $37^{\circ} \mathrm{C}$ for $1 \mathrm{~h}$. The reaction was quenched by adding $1 \mathrm{M}$ of $\mathrm{HCl}$ and pyridine (270970, Sigma). Benzenesulfonyl chloride (BSC, Sigma) was then added to the reaction mixture. After mixing for $1 \mathrm{~min}$, it was placed on ice, and its color changes were then measured with a spectrophotometer at $325 \mathrm{~nm}$. ACE inhibition was calculated using the equation, $[(B-A) /(B-C)] \times 100$, where $B$ is the absorbance with ACE and HHL without the ACE inhibitor component; $A$ is the absorbance with ACE; HHL and C are the absorbance with the HHL without ACE and ACE inhibitor components, respectively.

\subsection{Statistical Analysis}

A statistical analysis was conducted using the SPSS version 20.0 (IBM Corp., Armonk, NY, USA). The results were presented as means \pm standard deviations or frequency distributions. A one-way analysis of variance (ANOVA) was used to analyze the significant differences in the TMK samples according to the different regions. A Tukey's test was conducted for multiple comparisons between groups; $p$ values $<0.05$ were considered significant.

\section{Results}

\subsection{Sodium Contents and Biogenic Amine Contents}

KS contained sodium contents that were significantly lower than the other TMK. The contents of biogenic amine, including histamine and tyramine, appeared to be different among the Kochujang from five different provinces. Owing to the large variations, they were similar among Kochujang samples (Table 1). The biogenic amine productions were related to the contents of Bacillus spp. to produce biogenic amines.

Table 1. Histamine, tyramine, and sodium contents in traditionally made Kochujang (TMK) samples from different areas of Korea.

\begin{tabular}{cccccc}
\hline & KS $(n=\mathbf{1 2})$ & JL $(n=23)$ & GK $(n=17)$ & CC $(n=15)$ & JJ $(n=6)$ \\
\hline Sodium $(\%)$ & $2.17 \pm 0.19^{\mathrm{b}}$ & $2.69 \pm 0.09^{\mathrm{a}}$ & $2.61 \pm 0.14^{\mathrm{a}}$ & $2.45 \pm 0.14^{\mathrm{a}}$ & $2.49 \pm 0.30^{\mathrm{a}, *}$ \\
Histamine $(\mathrm{mg} / \mathrm{kg})$ & $19.5 \pm 12.4$ & $22.3 \pm 7.0$ & $43.1 \pm 4.7$ & $61.1 \pm 15.8$ & $13.0 \pm 5.83$ \\
Tyramine $(\mathrm{mg} / \mathrm{kg})$ & $49.4 \pm 26.2$ & $27.8 \pm 10.5$ & $54.9 \pm 19.9$ & $28.1 \pm 17.0$ & $45.5 \pm 31.2$ \\
\hline
\end{tabular}

Values indicated means \pm standard errors. TMK samples from Jeolla ((JL), Jeonbuk+Jeonnam; $n=12)$, Kyungsang ((KS), Kyungbuk + Kyungnam; $n=12)$, Geongkang $((\mathrm{GK})$, Geonggi-Do+Incheon+Kwangwon; $n=17)$, and Chungcheung provinces $((\mathrm{CC})$, Chungbuk $+\mathrm{Chungnam;} n=15)$ and Jeju island $((\mathrm{JJ}) ; n=6)$ of Korea. * Significantly different among the TMK from different provinces at $p<0.05 .{ }^{\mathrm{a}, \mathrm{b}}$ Different letters on the bars indicate significant differences between the groups by Tukey test $(p<0.05)$.

\section{2. $\alpha$-and $\beta$-Diversity of the Bacterial Community of TMK from Five Different Provinces of Korea}

The $\alpha$-diversity was determined using the Chao1 and Shannon index representing bacterial richness in TMK. The TMK samples from JL and JJ showed the highest Chao1 index. CC had the lowest index among the groups ( $p=0.012$; Figure 3A). The Shannon index also showed a similar trend to the Chao1 index. The Shannon index of JL and JJ was higher than the other groups ( $p=0.016$; Figure 3B).

The $\beta$-diversity, a measure of similarity and dissimilarity of bacterial communities, was significantly different among the TMK of five different provinces $(p=0.003$; Figure $3 C)$. The bacterial communities of KS were separated from those of JL, JJ, and CC. The PCoA1 and PCoA2 axis explained $10.99 \%$ and $4.06 \%$ of bacterial diversity of all TMK samples (Figure 2C). 


\subsection{Bacterial Community of TMK from Five Different Provinces of Korea}

Among TMK from different provinces of Korea, bacterial communities of KS were different from those of other TMK samples. KS had a much lower Bacillaceae ( $65 \%)$ than the other TMK in the family level, while TMK in JJ and CC had approximately $90 \%$ Bacillaceae, and JL and GK contained approximately $80 \%$ (Figure 4A). Interestingly, TMK in JL and GK contained approximately 9.3 and $4.4 \%$ Lactobacillaceae, whereas those in other provinces had less than 1\% (Figure 4A). KS included much less Bacillus and higher Enterococcus and Staphylococcus at the genus level than the other TMK, but JL and GK contained much higher Lactobacillus than the TMK. CC and JJ contained more than $90 \%$ Bacillus (Figure 4B).

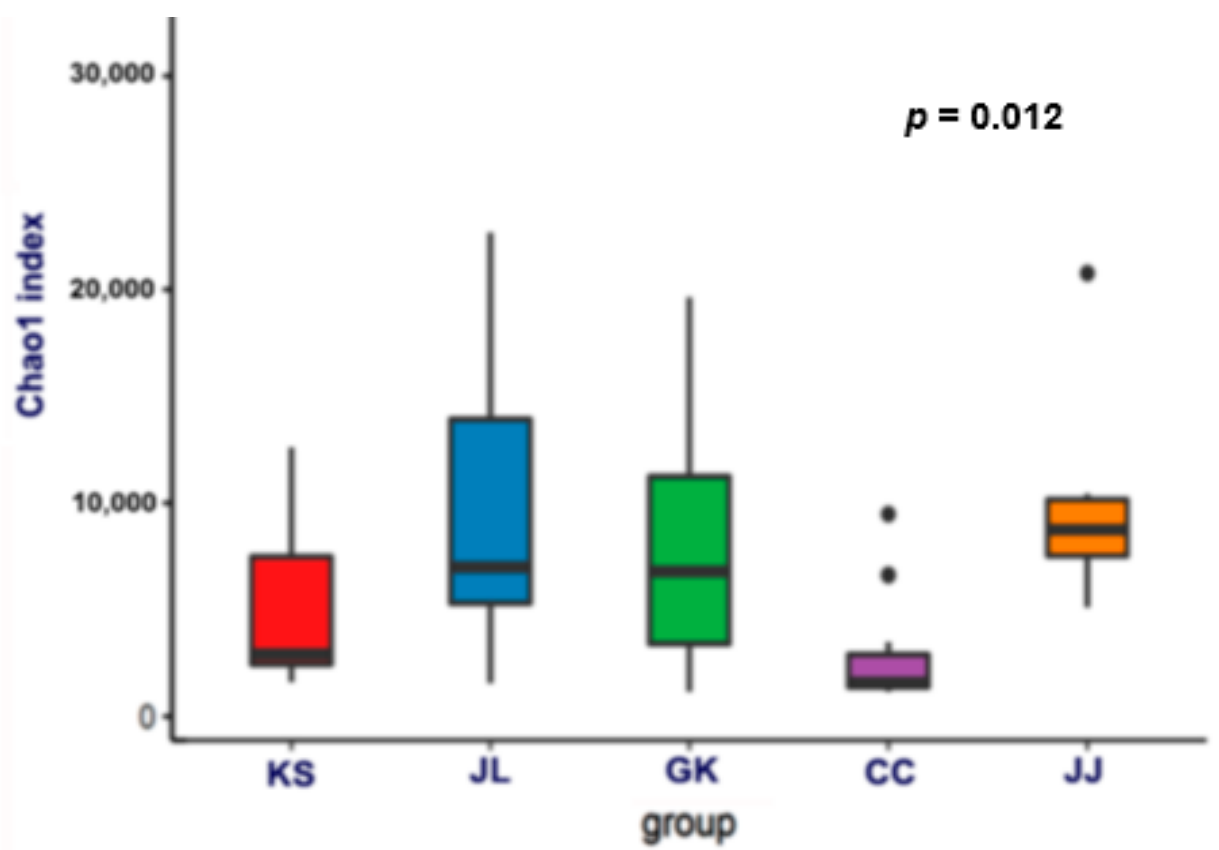

(A)

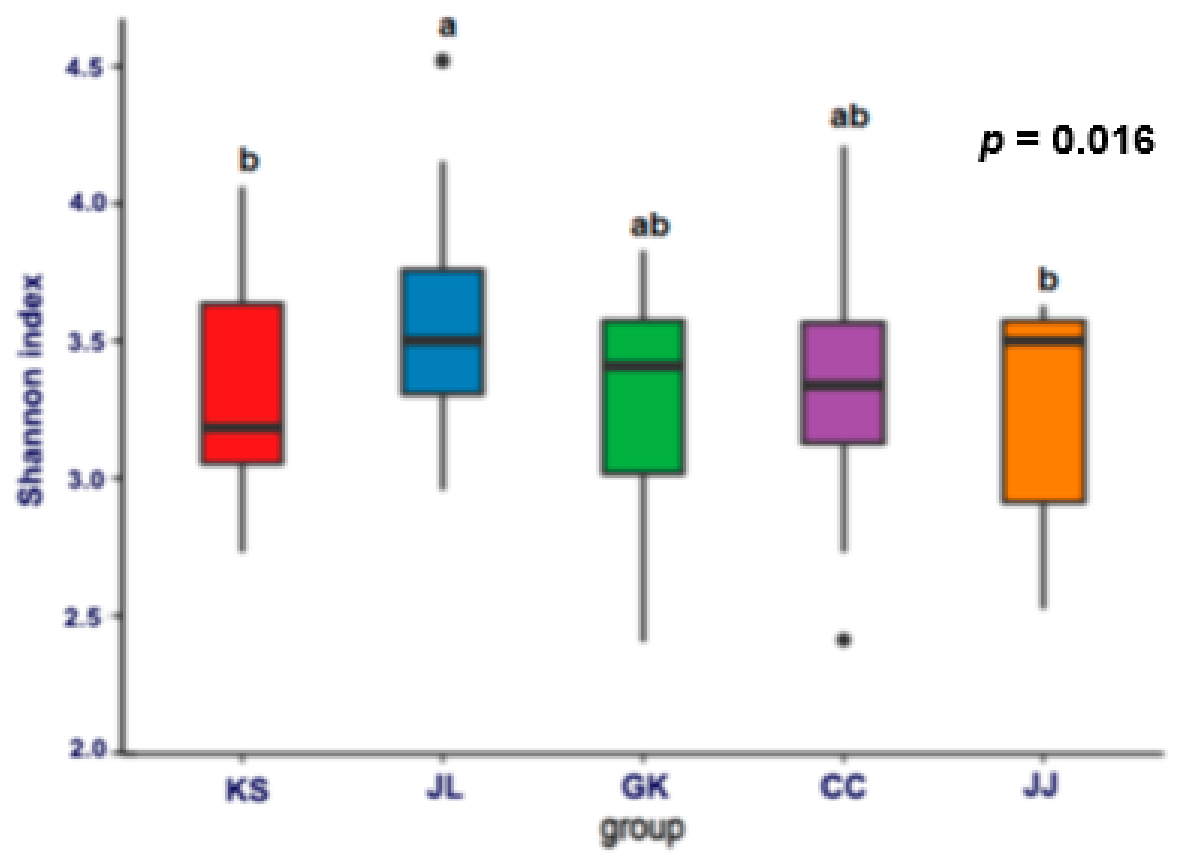

(B)

Figure 3. Cont. 


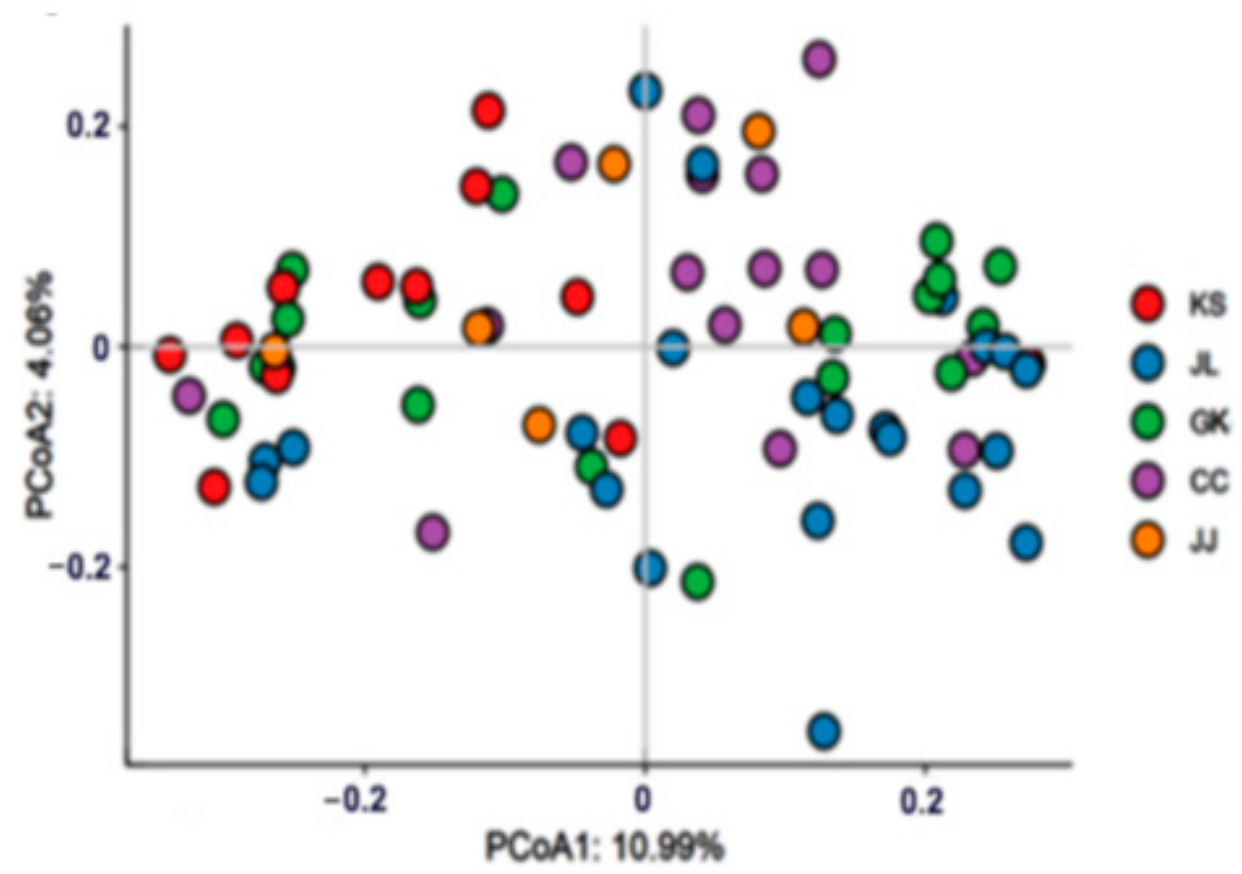

(C)

Figure 3. The richness of bacteria in traditionally made Kochujang (TMK). (A) Chao1 index for $\alpha$-diversity. (B) Shannon index for $\alpha$-diversity. (C) $\beta$-diversity. TMK samples from Jonlla (Chonbuk + Chonnam; $n=23)$, Kyungsang ((KS) Kyungbuk + Kyungnam; $n=12)$, Gyungkang ((GK) Gyunggi-Do + Kwangwon; $n=17)$, and Chungcheung provinces ((CC) Chungbuk + Chungnam; $n=15)$ and Jeju island ((JJ); $n=6)$ of Korea. a and b: Different letters on the bars indicate significant differences among the groups by Tukey test $(p<0.05)$.

\subsection{Beneficial Bacteria in TMK from Five Different Provinces of Korea}

TMK contained 35 beneficial bacteria, and the primary beneficial bacteria were B. subtilis in all TMK. On the other hand, KS (26\%) did not include B. subtilis as much as TMK from other provinces ( 40\%) (Figure 4C). Interestingly, KS contained 7\% Enterococcus and E. faecium, but the other TMK did not include it as much. Other beneficial bacteria in TMK were B. subtilis, B. coagulans, Bacteroides vulgatus, Lactobacillus plantarum, Enterococcus faecium, Pediococcus acidilactici, and Weissella confuse (Figure 4C).

On the other hand, TMK contained harmful bacteria, including Escherichia coli, Acinetobacter baumannii, Staphylococcus aureus, B. cereus, Proteus mirabilis, Pseudomonas aeruginosa, Morganella morganii, and Hafnia alvei. JL contained the highest harmful bacteria among the TMK groups (Figure 4D). On the other hand, the mean contents of harmful bacteria in five TMK groups were less than $0.1 \%$ in all TMK groups except Acinetobacter baumannii in JJ and Staphylococcus aureus in JL TMK also contained B. cereus in all five TMK groups, but their contents were less than $0.1 \%$. KS and JL contained B. cereus more than the other groups (Figure 4E). TMK included restricted bacteria for foods, including Leuconostoc pseudomesenteroides, Arthrobacter globiformis, Corynebacterium glutamicum, Staphylococcus carnosus, and Acetobacter aceti. KS contained restricted bacteria for foods, particularly Leuconostoc pseudomesenteroides and Acetobacter aceti, the most among the five TMK groups (Figure 4E). However, the total contents of harmful and restricted bacteria were less than $0.5 \%$ of TMK and can be acceptable for foods.

\subsection{Metabolic Activities of the Bacteria in Area Groups of TMK by PICRUSt2 Analysis}

Gene expression of bacteria in the TMK samples from the different areas showed significant differences in the relative abundance of the Kyoto Encyclopedia of Genes and Genomes Orthology (KO) involved in LPS biosynthesis, alanine, aspartate, glutamate metabolism, cofactor biosynthesis, thiamine metabolism, biotin metabolism, fructose, and 
mannose metabolism $(p<0.05$; Table 2$)$. Gene expression related to the LPS biosynthesis $(p<0.01)$ and fructose and mannose metabolism $(p<0.001)$ was higher in TMK of the KS area than that of other areas. On the other hand, gene expression related to alanine, aspartate, and glutamate metabolism was higher in TMK of JL and GK than in the other areas. TMK from KS showed lower gene expression involved in cofactor biosynthesis, thiamine metabolism, and biotin metabolism than JL and GK (Table 2).

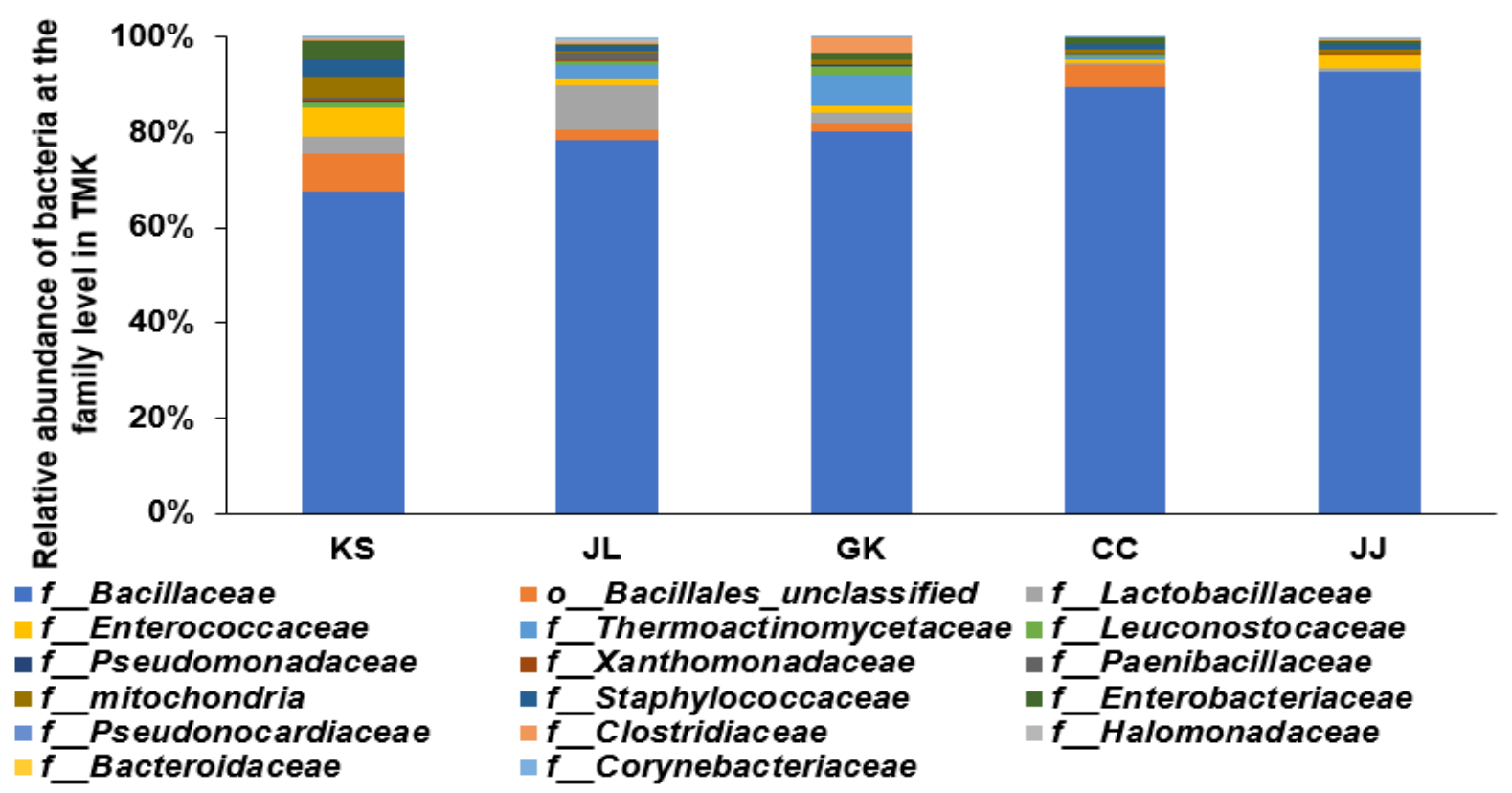

(A)

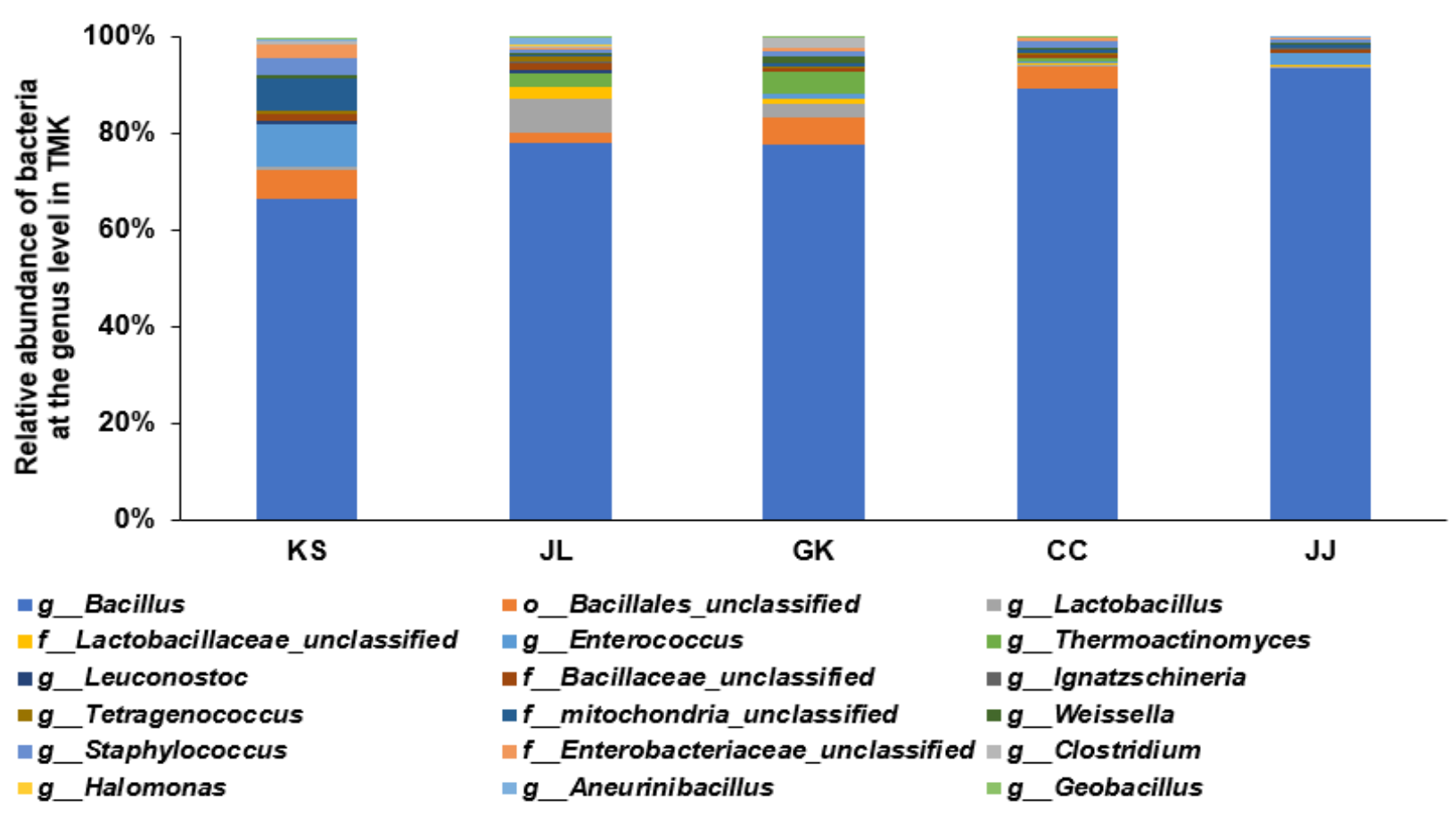

(B)

Figure 4. Cont. 


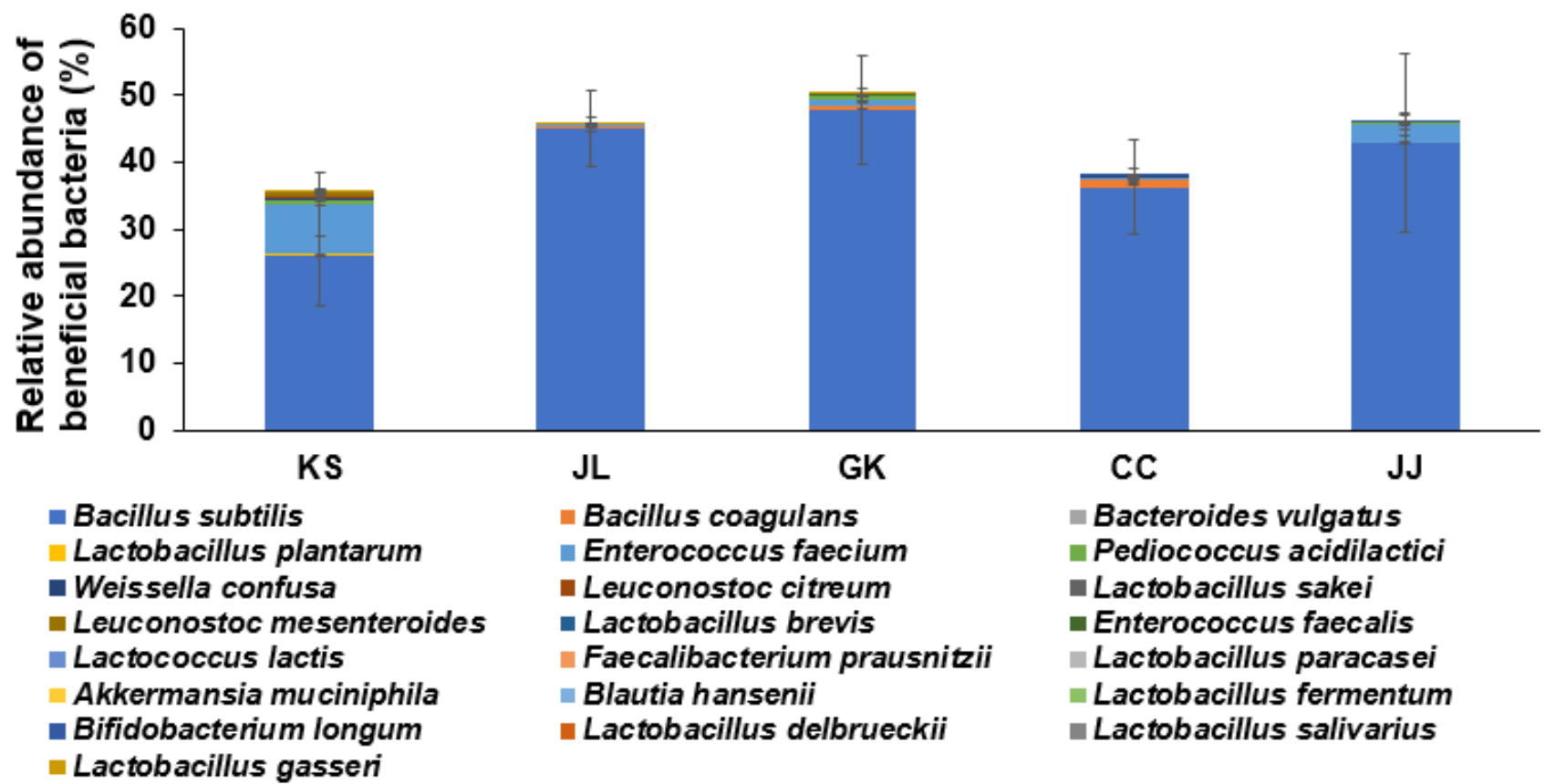

(C)

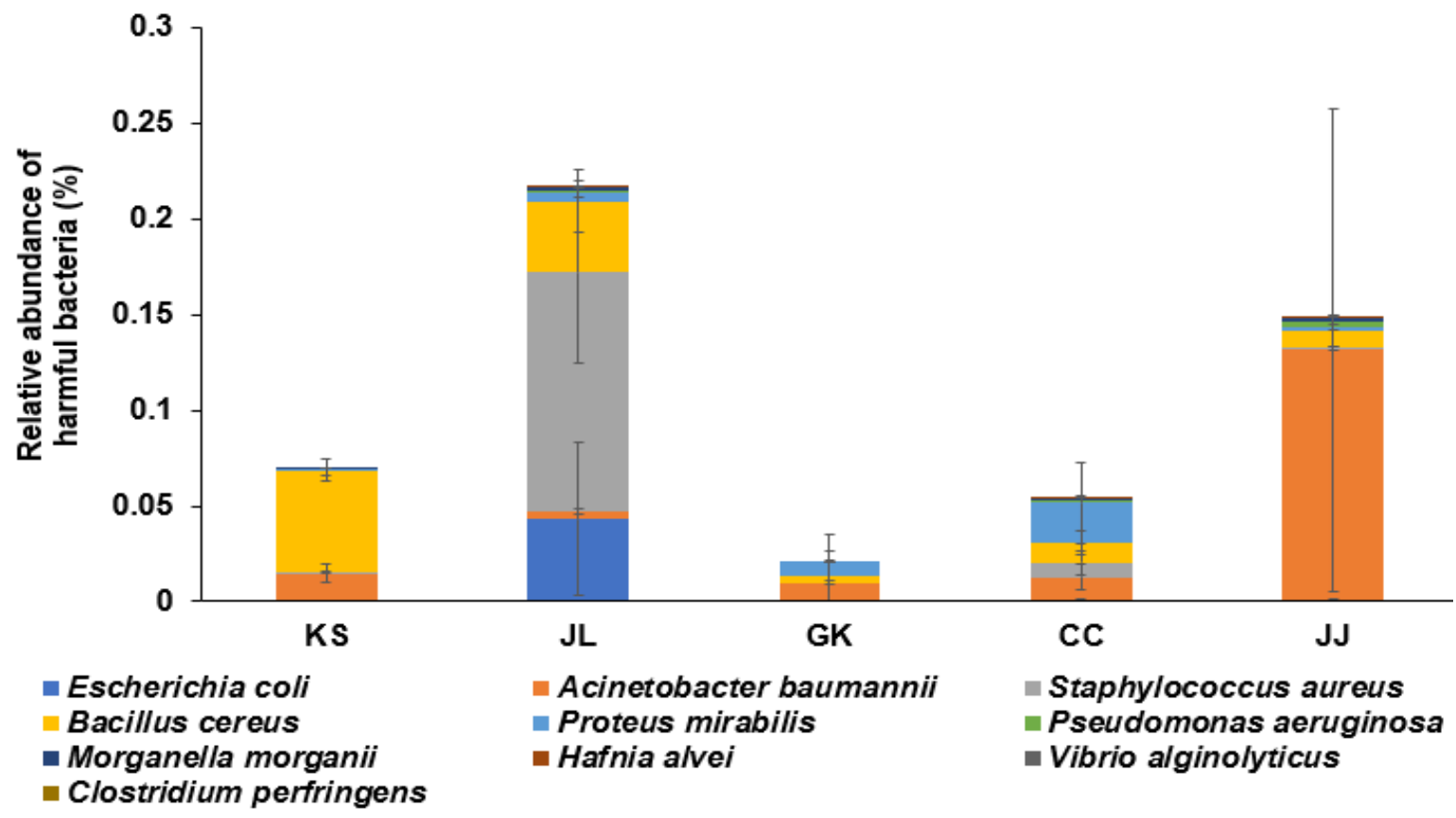

(D)

Figure 4. Cont. 


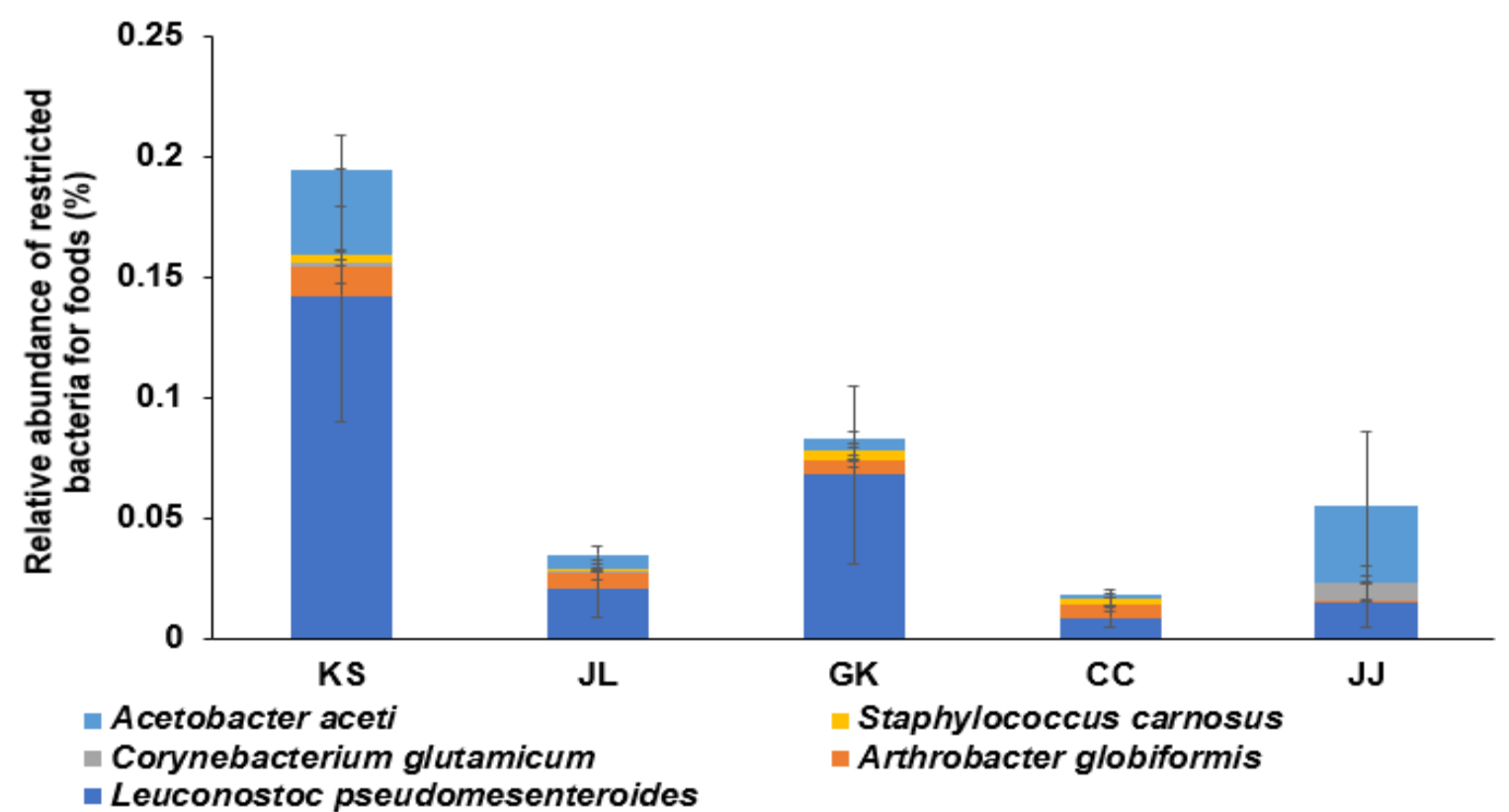

(E)

Figure 4. Bacterial communities of traditionally made Kochujang (TMK). (A) Relative abundance at the family level of bacteria. (B) Relative abundance at the genus level of bacteria. (C) Percentage of known beneficial bacteria at the species level. (D) Percentage of known harmful bacteria at the species level. (E) Percentage of restricted bacteria for food usage at the species level. TMK samples from Jonlla (Chonbuk + Chonnam; $n=23)$, Kyungsang ((KS) Kyungbuk + Kyungnam; $n=12)$, Gyungkang ((GK) Gyunggi-Do + Kwangwon; $n=17)$, Chungcheung provinces ((CC) Chungbuk + Chungnam, $n=15)$ and Jeju island $((\mathrm{JJ}) ; n=6)$ of Korea.

Table 2. The proportion of the Kyoto Encyclopedia of Genes and Genomes Orthology values of the TMK bacterial genes involved in respective metabolism determined by Picrust 2 .

\begin{tabular}{|c|c|c|c|c|c|}
\hline & $\mathrm{KS}(n=12)$ & $\mathrm{JL}(n=23)$ & GK $(n=17)$ & $\mathrm{CC}(n=15)$ & $\mathrm{JJ}(n=6)$ \\
\hline LPS biosynthesis & $0.15 \pm 0.05^{a}$ & $0.03 \pm 0.01^{b}$ & $0.04 \pm 0.02^{b}$ & $0.03 \pm 0.016^{b}$ & $0.01 \pm 0.01^{\mathrm{b}, * *}$ \\
\hline $\begin{array}{l}\text { Fructose and mannose } \\
\text { metabolism }\end{array}$ & $1.36 \pm 0.12^{\mathrm{a}}$ & $1.12 \pm 0.03^{b}$ & $1.18 \pm 0.06^{b}$ & $1.18 \pm 0.03^{b}$ & $1.17 \pm 0.09^{b, * * *}$ \\
\hline $\begin{array}{l}\text { Alanine, aspartate, and } \\
\text { glutamate metabolism }\end{array}$ & $1.35 \pm 0.02^{b}$ & $1.44 \pm 0.01^{\mathrm{a}}$ & $1.43 \pm 0.01^{\mathrm{a}}$ & $1.39 \pm 0.01^{b}$ & $1.39 \pm 0.02^{b, * * *}$ \\
\hline Cofactor biosynthesis & $6.50 \pm 0.12^{b}$ & $6.89 \pm 0.06^{\mathrm{a}}$ & $6.91 \pm 0.13^{\mathrm{a}}$ & $6.79 \pm 0.04^{\mathrm{a}, \mathrm{b}}$ & $6.78 \pm 0.09^{a, b, *}$ \\
\hline Thiamine metabolism & $0.79 \pm 0.02^{b}$ & $0.89 \pm 0.02^{a}$ & $0.87 \pm 0.01^{\mathrm{a}}$ & $0.85 \pm 0.01^{\mathrm{a}, \mathrm{b}}$ & $0.86 \pm 0.03^{a, b, * *}$ \\
\hline Biotin metabolism & $0.71 \pm 0.03^{b}$ & $0.80 \pm 0.01^{\mathrm{a}}$ & $0.76 \pm 0.02 \mathrm{a}^{\mathrm{b}}$ & $0.77 \pm 0.02^{\mathrm{a}}$ & $0.77 \pm 0.03^{a, b, *}$ \\
\hline
\end{tabular}

Values indicated means \pm standard deviations. Traditionally made Kochujang (TMK) samples from Jeolla ((JL), Jeonbuk + Jeonnam; $n=12)$, Kyungsang ((KS), Kyungbuk + Kyungnam; $n=12)$, Geongkang ((GK), Geonggi-Do + Incheon + Kwangwon; $n=17)$, and Chungcheung provinces ((CC), Chungbuk + Chungnam; $n=15)$ and Jeju island $((\mathrm{JJ}) ; n=6)$ of Korea. ${ }^{*}$ Significantly different among the TMK from different provinces at $p<0.05,{ }^{* *}$ at $p<0.01,{ }^{* * *}$ at $p<0.001$. a,b Different letters on the bars indicate significant differences between the groups by Tukey test $(p<0.05)$.

\subsection{Antioxidant, Fibrinolytic, and ACE Inhibitory Activities}

Bacillus spp. with the potential activity to protect against cerebrovascular diseases were selected from the TMK. The Bacillus spp. can be used to make an inoculated Kochujang with anti-cerebrovascular diseases. B. subtilis (SRCM117233, SRCM117245, and SRCM117253) and B. velezensis (SRCM117254) had a high reactive oxygen species removing capacity (DPPH\%) and SOD-like activity (Table 3). B. subtilis SRCM117233, SRCM117245, SRCM117253, and SRCM117304, B. velezensis SRCM117300, SRCM117301, SRCM117314, and SRCM117318, and B. amyloliquefaciens SRCM117311 had fibrinolytic activity with a more than $6 \mathrm{~cm}$ clear zone (Table 3). B. subtilis had high fibrinolytic activity compared with 
the other Bacillus spp. Only B. velezensis SRCM117254, SRCM117311, SRCM117314, and SRCM117318 had more than 10\% ACE inhibitory activity (Table 3).

Table 3. Functionalities of isolated Bacillus spp. from traditionally made Kochujang.

\begin{tabular}{cccccc}
\hline SRCM No. & Bacteria ID & $\begin{array}{c}\text { ROS Removing } \\
\text { Capacity (DPPH\%) }\end{array}$ & $\begin{array}{c}\text { SOD-Like } \\
\text { Activity (\%) }\end{array}$ & $\begin{array}{c}\text { Fibrinolytic Activity } \\
\text { (Diameter, mm) }\end{array}$ & $\begin{array}{c}\text { ACE Inhibitory } \\
\text { Activity (\%) }\end{array}$ \\
\hline SRCM117233 & B. subtilis & $15.9 \pm 0.86$ & $44.8 \pm 2.66$ & $68.4 \pm 0.58$ & $3.09 \pm 0.55$ \\
SRCM117245 & B. subtilis & $22.3 \pm 0.39$ & $26.6 \pm 3.47$ & $80.6 \pm 0.47$ & $6.43 \pm 0.29$ \\
SRCM117253 & B. subtilis & $16.5 \pm 0.16$ & $47.3 \pm 1.74$ & $77.3 \pm 7.02$ & $5.45 \pm 0.67$ \\
SRCM117254 & B. velezensis & $18.1 \pm 1.03$ & $25.4 \pm 4.50$ & $38.7 \pm 6.06$ & $13.3 \pm 0.00$ \\
SRCM117323 & B. subtilis & $10.7 \pm 0.32$ & - & $50.4 \pm 2.77$ & $9.96 \pm 0.00$ \\
SRCM117300 & B. velezensis & $9.22 \pm 0.87$ & - & $83.6 \pm 0.34$ & $9.19 \pm 0.30$ \\
SRCM117301 & B. velezensis & $14.2 \pm 0.16$ & - & $96.3 \pm 2.84$ & $6.73 \pm 0.41$ \\
SRCM117304 & B. subtilis & $15.7 \pm 1.90$ & $16.5 \pm 3.19$ & $84.5 \pm 11.2$ & $3.64 \pm 0.32$ \\
SRCM117311 & B. amyloliquefaciens & $3.37 \pm 0.56$ & - & $72.1 \pm 0.58$ & $20.1 \pm 1.22$ \\
SRCM117314 & B. velezensis & $6.85 \pm 0.71$ & - & $92.1 \pm 1.29$ & $18.6 \pm 0.19$ \\
SRCM117318 & B. velezensis & $15.9 \pm 0.64$ & $17.0 \pm 4.06$ & $76.4 \pm 0.03$ & $14.1 \pm 0.37$ \\
\hline
\end{tabular}

Values represented as means \pm SD $(n=3)$. No detection. ROS: reactive oxygen species; SOD: superoxide dismutase; ACE: angiotensin I converting. -, no activity.

\subsection{Probiotics Characteristics of Bacillus spp. Isolated from TMK}

Table 3 lists the Bacillus spp. with probiotic properties. The predominant Bacillus spp. in TMK were B. subtilis, B. velezensis, and B. amyloliquefaciens. Twelve isolated Bacillus spp. from TMK had more than $50 \%$ survival rates at $\mathrm{pH} 2.5$ and $0.3 \%$ oxgall, suggesting that 12 Bacillus spp. had acid-tolerance and bile salt tolerance, and more than $50 \%$ of them can go to the colon (Table 4). Interestingly, B. subtilis (SRCM117323) and B. amyloliquefaciens (SRCM117311) had 51.1 and $33.7 \%$ adhesion ability to colon cells, respectively (Table 4). Thus, they can stay in the colon to influence the host's health.

Table 4. Probiotic characteristics of Bacillus spp. isolated from traditionally made Kochujang.

\begin{tabular}{|c|c|c|c|c|c|c|}
\hline SRCM No. & Bacteria ID & Survival at $\mathrm{pH} 2.5(\%)^{1}$ & $\begin{array}{l}\text { Survival at } 0.3 \% \\
\text { Oxgall (\%) }\end{array}$ & $\begin{array}{c}\text { Adhesion } \\
\text { Ability to } \\
\text { Colon Cell (\%) }\end{array}$ & $\begin{array}{c}\text { Biogenic } \\
\text { Amine-Related } \\
\text { Genes }^{2}\end{array}$ & $\begin{array}{l}\text { B. cereus Related } \\
\text { Gene Expression }{ }^{3}\end{array}$ \\
\hline SRCM117233 & B. subtilis & $67.1 \pm 2.43$ & $76.3 \pm 0.75$ & - & - & - \\
\hline SRCM117245 & B. subtilis & $63.7 \pm 1.10$ & $64.3 \pm 0.91$ & - & - & - \\
\hline SRCM117253 & B. subtilis & $62.8 \pm 1.46$ & $65.2 \pm 1.43$ & - & - & - \\
\hline SRCM117254 & B. velezensis & $83.6 \pm 2.20$ & $84.2 \pm 1.39$ & - & - & - \\
\hline SRCM117323 & B. subtilis & $105.5 \pm 5.27$ & $96.2 \pm 3.94$ & $51.1 \pm 0.92$ & - & - \\
\hline SRCM117300 & B. velezensis & $54.3 \pm 0.80$ & $51.5 \pm 1.58$ & - & - & - \\
\hline SRCM117301 & B. velezensis & $62.8 \pm 2.73$ & $59.7 \pm 1.10$ & - & - & - \\
\hline SRCM117304 & B. subtilis & $112.0 \pm 1.77$ & $68.5 \pm 0.48$ & - & - & - \\
\hline SRCM117311 & B. amyloliquefaciens & $89.5 \pm 1.56$ & $89.8 \pm 1.17$ & $33.7 \pm 2.45$ & - & - \\
\hline SRCM117314 & B. velezensis & $68.9 \pm 1.29$ & $62.8 \pm 2.12$ & - & - & - \\
\hline SRCM117318 & B. velezensis & $90.6 \pm 0.73$ & $75.8 \pm 1.22$ & - & - & - \\
\hline
\end{tabular}

Values represented as means $\pm \mathrm{SD}(n=3) .{ }^{1}$ The percentage of the number of live cells after the reaction and before the reaction. ${ }^{2}$ Determined by histidine decarboxylase (hdc) and tyrosine decarboxylase (tdc) expression. ${ }^{3} \mathrm{CytK}$, nheA, ent FM, bceT, hblC, CER gene expression related to B. cereus. -, no activity.

None of the eleven Bacillus spp. had histidine decarboxylase $(h d c)$ and tyrosine decarboxylase $(t d c)$ gene expression, indicating that they did not produce biogenic amines, histamine, and tyramine (Table 4). Bacillus spp. was not also detected with the expression of six endotoxin genes ( $C y t K$, nheA, ent FM, bceT, hblC, CER) related to B. cereus (Table 4). The results suggest that the isolated Bacillus spp. did not produce B. cereus-related endotoxins.

\section{Discussion}

TMK is a type of Jang, which are long-term fermented soybeans in Korea. Unlike doenjang, however, it includes red pepper powder, malted grains and mainly rice. Kochujang $(5 \%)$ contains less salt than doenjang $(\sim 12 \%)$ [27]. The differences in their compositions 
influence the bacteria communities. The present study compared the bacterial communities of 73 TMK samples from different provinces and identified the probiotic properties with anti-cerebrovascular diseases of the isolated Bacillus spp. KS TMK samples contained lower sodium contents than the other TMK samples, and bacterial distribution was highly different. The bacterial community must be investigated to control TMK quality by reducing harmful bacteria and biogenic amine contents and increase beneficial bacteria. Moreover, the specific Bacillus spp. needs to be isolated and the functionalities identified to make TMK with specific functionalities. However, a few studies have identified the bacteria community of TMK, and the functionalities of isolated Bacillus spp. from TMK have not been examined. The present study identified the bacterial community and metabolic function of TMK from five different areas and isolated Bacillus spp. having anti-cerebrovascular disease function. The results can be used to control the TMK quality in Korea, and inoculated Kochujang with an anti-cerebrovascular disease can be made and commercialized.

In Asian countries, there are several types of fermented soybean products, including natto, tempeh, douche, and sufu [28]. They are similar to chungkookjang and doenjang in Korea. In China, Doubanjiang is made by adding crushed red pepper to the broad fermented beans and wheat flour with $10-12 \%$ salts for two to three months (meju). The mixed meju and red pepper were ripened for more than 12 months. Doubanjiang is similar to Kochujang in Korea. On the other hand, its bacteria community is different from TMK. Doubanjiang contains high in proteobacteria ( 50\%) and Firmicutes ( 40\%) at the phylum level, whereas $40 \%$ of bacteria were not identified at the genus level, and the identified ones included Bacillus (7.5\%), Pantoea (7\%), Halomonas (6.4\%), Lactobacillus (5.5\%), Sphingomonas $(5.4 \%)$, and Staphylococcus (5\%) after a 12-month aging [29]. It indicated that the bacterial distribution was quite different between TMK and doubanjiang. The different bacterial distributions between TMK and doubanjiang might be due to the differences in the red pepper state and salt contents.

Although the dominant bacteria, Bacillus spp., were similar in TMK and doenjang, TMK contained more diverse bacterial communities than doenjang because of the digested rice powder and lower salt contents in TMK than doenjang [5]. TMK from different areas in Korea may have different bacterial distributions and temperatures. Unlike chungkookjang, a few studies of the TMK bacterial communities have been published, and the metabolic function of the bacteria in TMK has not been studied. The sodium contents in doenjang were reported to have a different bacterial distribution [30]. The lower salt contents ( $9 \%$ and $12 \%$ ) in doenjang decreased the $\mathrm{pH}$ and increased the microbial abundance, particularly Weissella, Tetragenococcus, Oceanobacillus, Debaryomyces, and Lactobacillus [30]. Although the effect of salt content (5-7\%) on the bacteria community has not been investigated in TMK, it may exhibit a similar impact to doenjang. The lower salt in TMK reduces Bacillus and promotes the diversity and abundance of bacteria when its quality is well-controlled and maintained. However, in KS TMK, beneficial bacteria were lower and harmful bacteria were higher than other TMK. JL and CK contained some Lactobacillus. The bacterial community differences in TMK from doenjang might be due to sodium, carbohydrate contents, and environmental temperature in the present study. Therefore, TMK can have high beneficial and diverse bacteria when its production has better control during the fermented and aging periods.

The bacterial communities of TMK in KS were separated significantly from those of TMK in other areas in the $\beta$-diversity analysis. KS contained the lowest Bacillus spp. $(\sim 60 \%)$. Moreover, the bacteria distribution in KS TMK was separated from the other TMK except for JJ TMK in $\beta$-diversity. Ryu et al. [7] reported that the TMK from Northern and Southern parts of KS contain Bacillus (54.7\%), Aerosakkonema (23.8\%), and Enterococcus $(8.5 \%)$, which are abundant bacteria at the genus level after fermentation. Consistent with the Bacillus proportion in the Ryu et al. [7] study, the Bacillus proportion was much lower in KS TMK than the other TMK; while KS TMK, but not TMK from the other areas, contained approximately 10\% Enterococcus and 8\% Leuconostoc. TMK from JL and GK contained approximately $8 \%$ and 3\% Lactobacillus. On the other hand, the bacteria composition at the 
species level was somewhat different between Ryu et al. and the present studies: B. haynesii, and B. licheniformis are dominant after fermentation, and E. hirae and E. faecium exist in the TMK according to Ryu et al. [7]. The present study showed that $B$. subtilis was dominant, and B. velezensis and B. coagulans were abundant in TMK.

The differences in bacterial distribution influenced the biogenic amine contents to influence the TMK quality [31]. Doenjang made with a starter culture (inoculated doenjang) has been reported to contain less biogenic amine. In the present study, biogenic amine contents were varied among TMK from different areas, and they were lower in JL than TMK from other areas. In estimating the metabolic function through Picrust2, KS TMK showed a lower LPS biosynthesis and a lower vitamin metabolism compared with TMK from other areas. However, in the present study, the biogenic amine metabolism in the Picrust2 analysis was not shown in TMK, even though gene expression of $t d c$ and $h d c$ was detected in some TMK. It suggests that the collected TMK did not have a high biogenic amine metabolism. In addition, a large sample size is needed to detect the bacterial distribution because the bacterial composition varies among the TMK samples. In Ryu et al. [7], regional differences in bacteria are not shown, but the result may be related to the small sample size. The sample size should be more than 10 in each province to show statistical significance. There are more than 10 samples in each area group in the present study except for JJ because Jeju is small and less varied. The present study showed that TMK from KS had a significantly different bacterial distribution from other areas.

TMK has been reported to have anti-obesity, antidiabetic, anti-dyslipidemic activities in cell-based, animal, and human studies [4,10-12,32]. These activities were mainly related to the metabolites of TMK containing amino acids, organic acids (citric acid), fatty acids (oleic acid and linoleic acid), sugars and sugar alcohols, flavonoids (luteolin- $C$-hexoside, quercetin-O-rhamnoside, and genistein $O$-dihexoside), capsaicinoids (capsaicin and dihydrocapsaicin) and capsinoids (dihydrocapsiate), and phospholipids [33]. On the other hand, few studies have examined the metabolic function of bacteria in TMK. Different bacteria in TMK make different metabolites contributing to different metabolic functions. Grains, mostly rice, are used as a carbohydrate source, but other grains are also substituted for rice. TMK with rice and wheat as koji have different antioxidant activities, and their metabolites are somewhat different [25]. The differences in metabolites are involved in growing different bacteria better in different grains. In previous studies, the predominant bacteria in Jang, including TMK, was Bacillus, and Bacillus spp. were isolated from doenjang, chungkookjang, and TMK [25]. Chungkookjang, and chungkookjang inoculated with antidiabetic activity was made from isolated Bacillus spp. On the other hand, some Bacillus spp. isolated from doenjang and TMK, have not been used to produce the inoculated doenjang and TMK.

The bacteria compositions of TMK affect its quality, including taste, odor, and metabolic functions. In the present study, some B. subtilis strains in TMK had higher antioxidant and high fibrinolytic activity, while some $B$. velezensis strains had more than $10 \%$ ACE inhibitory activity. Previous studies showed that tomato fermented with $B$. subtilis, sardinelle protein fermented with B. subtilis A26, and B. amyloliquefaciens An6, and Ruditapes philippinarum fermented with $B$. natto have shown ACE inhibitory and antioxidant activities [34-36]. On the other hand, few studies have examined Bacillus spp. to have ACE inhibitory activity. The Bacillus spp. to have antioxidant, ACE inhibitory, and fibrinolytic activities did not have biogenic amine and Bacillus cereus-related genes. They can be used to make inoculated Kochujang with anti-cerebrovascular diseases.

Overall, TMK from all areas in Korea exhibited sustainable quality control, but KS TMK must increase beneficial bacteria in the present study. TMK should maintain optimal quality control to increase various beneficial bacteria and to not contain harmful bacteria and biogenic amines. Several B. subtilis, B. amyloliquefaciens, and B. velezensis had anticerebrovascular disease activity, including increasing fibrinolytic, antioxidant, and ACE inhibitory activity. The isolated ones can be applied to make functional Kochujang as a starter culture. The inoculated Kochujang can be registered as a functional food having 
anti-cerebrovascular disease activity in the Korean Food and Drug Administration after its efficacy and mechanism are confirmed in animal and human studies in the near future.

\section{Conclusions}

Salt and carbohydrate contents and ambient bacteria from different areas influence the bacterial composition of TMK. TMK must be well-monitored and controlled to have good quality since it is susceptible to growing harmful bacteria due to lower salt and higher carbohydrate contents than doenjang. All TMK contained mostly beneficial bacteria and $<0.5 \%$ harmful and restricted bacteria, suggesting they were well-managed. However, KS TMK may have a lower quality of bacteria than the other TMK. It is better to produce inoculated Kochujang to include well-controlled bacteria and have specific functionality. Among the isolated Bacillus spp. for producing inoculated Kochujang, B. subtilis, and B. velezensis had probiotic properties, no biogenic amine producing genes, antioxidant, fibrinolytic, and ACE inhibitory activities. These B. subtilis and B. velezensis strains can be used as a starter culture to make inoculated Kochujang protect against cerebrovascular diseases. Further animal and human studies are needed to produce inoculated Kochujang with optimal quality control and investigate its functionality for anti-cerebrovascular diseases.

Author Contributions: Conceptualization, S.P. and D.-Y.J.; methodology, G.H., S.-J.J. and M.-S.R.; resources, D.-Y.J. and H.-J.Y.; data collection and analysis, G.H., M.-S.R. and H.-J.Y.; writing-original draft preparation, S.P.; writing-review and editing, D.-Y.J., S.P. and G.H.; supervision, D.-Y.J. All authors have read and agreed to the published version of the manuscript.

Funding: This work was supported by "functional research of fermented soybean food (safety monitoring)" under the Ministry of Agriculture, Food and Rural Affairs and partly Korea AgroFisheries and Food trade corporation in 2021.

Institutional Review Board Statement: Not applicable.

Informed Consent Statement: Not applicable.

Data Availability Statement: Data are available from the corresponding author on reasonable request with a reasonable reason.

Conflicts of Interest: The authors declare no conflict of interest.

\section{References}

1. Jeong, D.Y.; Jeong, S.Y.; Zhang, T.; Wu, X.; Qiu, J.Y.; Park, S. Chungkookjang, a soy food, fermented with Bacillus amyloliquefaciens protects gerbils against ishcmeic stroke injury, and post-stroke hyperglycemia. Food Res. Int. 2020, 128, 108769. [CrossRef] [PubMed]

2. Kwon, C.; Yu, H.T.; Roh, J.; Park, Y. Hyangyak-Jipsongbang; Department of Public Health: Korea, 1443 ; Volume 3.

3. Lee, M.B. Siksanjip; Korea, 18th Century.

4. Kwon, D.Y.; Hong, S.M.; Ahn, I.S.; Kim, Y.S.; Shin, D.W.; Park, S. Kochujang, a Korean fermented red pepper plus soybean paste, improves glucose homeostasis in 90\% pancreatectomized diabetic rats. Nutrition 2009, 25, 790-799. [CrossRef] [PubMed]

5. Jeong, S.J.; Ryu, M.S.; Yang, H.J.; Wu, X.H.; Jeong, D.Y.; Park, S.M. Bacterial Distribution, Biogenic Amine Contents, and Functionalities of Traditionally Made Doenjang, a Long-Term Fermented Soybean Food, from Different Areas of Korea. Microorganisms 2021, 9, 1348. [CrossRef] [PubMed]

6. Jeong, D.Y.; Daily, J.W.; Lee, G.H.; Ryu, M.S.; Yang, H.J.; Jeong, S.Y.; Qiu, J.Y.; Zhang, T.; Park, S. Short-Term Fermented Soybeans with Bacillus amyloliquefaciens Potentiated Insulin Secretion Capacity and Improved Gut Microbiome Diversity and Intestinal Integrity to Alleviate Asian Type 2 Diabetic Symptoms. J. Agric. Food Chem. 2020, 68, 13168-13178. [CrossRef]

7. Ryu, J.-A.; Kim, E.; Kim, M.-J.; Lee, S.; Yoon, S.-R.; Ryu, J.-G.; Kim, H.-Y. Physicochemical Characteristics and Microbial Communities in Gochujang, a Traditional Korean Fermented Hot Pepper Paste. Front. Microbiol. 2021, 11, 3543. [CrossRef]

8. Ali, I.; Abuissa, M.; Alawneh, A.; Subeh, O.; Abu Sneineh, A.; Mousa, S.; Deeb, I.; Rayyan, H. The Prevalence of Dyslipidemia and Hyperglycemia among Stroke Patients: Preliminary Findings. Stroke Res. Treat. 2019, 2019, 8194960. [CrossRef]

9. Park, S.; Kim, S.H.; Shin, J.Y. Combined association of skeletal muscle mass and grip strength with cardiovascular diseases in patients with type 2 diabetes. J. Diabetes 2021. [CrossRef]

10. Cha, Y.-S.; Kim, S.-R.; Yang, J.-A.; Back, H.-I.; Kim, M.-G.; Jung, S.-J.; Song, W.O.; Chae, S.-W. Kochujang, fermented soybean-based red pepper paste, decreases visceral fat and improves blood lipid profiles in overweight adults. Nutr. Metab. 2013, 10, 24. [CrossRef]

11. Lim, J.H.; Jung, E.S.; Choi, E.K.; Jeong, D.Y.; Jo, S.W.; Jin, J.H.; Lee, J.M.; Park, B.H.; Chae, S.W. Supplementation with Aspergillus oryzae-fermented kochujang lowers serum cholesterol in subjects with hyperlipidemia. Clin. Nutr. 2015, 34, 383-387. [CrossRef] 
12. Yang, H.J.; Kim, M.J.; Kim, K.S.; Lee, J.E.; Hong, S.P. In Vitro Antidiabetic and Antiobesity Activities of Traditional Kochujang and Doenjang and Their Components. Prev. Nutr. Food Sci. 2019, 24, 274-282. [CrossRef]

13. Choi, J.H.; Kim, J.E.; Kim, S.; Yoon, J.; Park, D.H.; Shin, H.J.; Lee, H.J.; Cho, S.S. Purification and partial characterization of a low molecular fibrinolytic serine metalloprotease $\mathrm{C} 142$ from the culture supernatant of Bacillus subtilis C142. Int. J. Biol. Macromol. 2017, 104, 724-731. [CrossRef]

14. Hitosugi, M.; Hamada, K.; Misaka, K. Effects of Bacillus subtilis var. natto products on symptoms caused by blood flow disturbance in female patients with lifestyle diseases. Int. J. Gen. Med. 2015, 8, 41-46. [CrossRef]

15. Hwang, J.; Kim, J.-C.; Moon, H.; Yang, J.-Y.; Kim, M. Determination of sodium contents in traditional fermented foods in Korea. J. Food Comp. Anal. 2017, 56, 110-114. [CrossRef]

16. Wu, X.; Unno, T.; Kang, S.; Park, S. A Korean-Style Balanced Diet Has a Potential Connection with Ruminococcaceae Enterotype and Reduction of Metabolic Syndrome Incidence in Korean Adults. Nutrients 2021, 13, 495. [CrossRef]

17. Vazquez, L.; Guadamuro, L.; Giganto, F.; Mayo, B.; Florez, A.B. Development and Use of a Real-Time Quantitative PCR Method for Detecting and Quantifying Equol-Producing Bacteria in Human Faecal Samples and Slurry Cultures. Front. Microbiol. 2017, 8, 1155. [CrossRef]

18. Eom, J.S.; Song, J.; Choi, H.S. Protective Effects of a Novel Probiotic Strain of Lactobacillus plantarum JSA22 from Traditional Fermented Soybean Food against Infection by Salmonella enterica Serovar Typhimurium. J. Microbiol. Biotechnol. 2015, 25, 479-491. [CrossRef]

19. Li, L.; Wen, X.; Wen, Z.; Chen, S.; Wang, L.; Wei, X. Evaluation of the Biogenic Amines Formation and Degradation Abilities of Lactobacillus curvatus from Chinese Bacon. Front. Microbiol. 2018, 9, 1015. [CrossRef]

20. Kim, J.-B.; Kim, J.-M.; Cho, S.-H.; Oh, H.-S.; Choi, N.J.; Oh, D.-H. Toxin Genes Profiles and Toxin Production Ability of Bacillus cereus Isolated from Clinical and Food Samples. J. Food Sci. 2011, 76, T25-T29. [CrossRef]

21. Jeong, S.; Shin, M.; Jeong, S.; Yang, H.; Jeong, D. Characteristic analysis and production of short-ripened Korean traditional soy sauce added with rice bran. J. Korean Soc. Food Sci. Nutr. 2014, 43, 550-556. [CrossRef]

22. Ryu, M.S.; Yang, H.J.; Jeong, S.J.; Seo, J.W.; Ha, G.; Jeong, S.Y.; Jeong, D.Y. Characteristic study and optimization of culture conditions for Bacillus amyloliquefaciens SRCM 100731 as probiotic resource for companion animal. Korean J. Microbiol. 2018, 54, 384-397.

23. Murakami, K.; Yamanaka, N.; Ohnishi, K.; Fukayama, M.; Yoshino, M. Inhibition of angiotensin I converting enzyme by subtilisin NAT (nattokinase) in natto, a Japanese traditional fermented food. Food Funct. 2012, 3, 674-678. [CrossRef]

24. Luo, S.; Jiang, X.; Jia, L.; Tan, C.; Li, M.; Yang, Q.; Du, Y.; Ding, C. In Vivo and In Vitro Antioxidant Activities of Methanol Extracts from Olive Leaves on Caenorhabditis elegans. Molecules 2019, 24, 704. [CrossRef]

25. Jeon, H.H.; Jung, J.Y.; Chun, B.-H.; Kim, M.-D.; Baek, S.Y.; Moon, J.Y.; Yeo, S.-H. Screening and Characterization of Potential Bacillus Starter Cultures for Fermenting Low-Salt Soybean Paste (Doenjang). J. Microbiol. Biotechnol. 2016, 26, 666-674. [CrossRef]

26. Ghanbari, R.; Zarei, M.; Ebrahimpour, A.; Abdul-Hamid, A.; Ismail, A.; Saari, N. Angiotensin-I Converting Enzyme (ACE) Inhibitory and Antioxidant Activities of Sea Cucumber (Actinopyga lecanora) Hydrolysates. Int. J. Mol. Sci. 2015, 16, 28870-28885. [CrossRef]

27. Han, D.M.; Chun, B.H.; Kim, H.M.; Jeon, C.O. Characterization and correlation of microbial communities and metabolite and volatile compounds in doenjang fermentation. Food Res. Int. 2021, 148, 110645. [CrossRef]

28. Jang, C.H.; Oh, J.; Lim, J.S.; Kim, H.J.; Kim, J.-S. Fermented Soy Products: Beneficial Potential in Neurodegenerative Diseases. Foods 2021, 10, 636. [CrossRef]

29. Zhang, L.; Che, Z.; Xu, W.; Yue, P.; Li, R.; Li, Y.; Pei, X.; Zeng, P. Dynamics of physicochemical factors and microbial communities during ripening fermentation of Pixian Doubanjiang, a typical condiment in Chinese cuisine. Food Microbiol. 2020, 86, 103342. [CrossRef]

30. Chun, B.H.; Kim, K.H.; Jeong, S.E.; Jeon, C.O. The effect of salt concentrations on the fermentation of doenjang, a traditional Korean fermented soybean paste. Food Microbiol. 2020, 86, 103329. [CrossRef]

31. Shukla, S.; Lee, J.S.; Park, H.K.; Yoo, J.A.; Hong, S.Y.; Kim, J.K.; Kim, M. Effect of Novel Starter Culture on Reduction of Biogenic Amines, Quality Improvement, and Sensory Properties of Doenjang, a Traditional Korean Soybean Fermented Sauce Variety. J. Food Sci. 2015, 80, M1794-M1803. [CrossRef]

32. Kwon, D.Y.; Daily, J.W., 3rd; Kim, H.J.; Park, S. Antidiabetic effects of fermented soybean products on type 2 diabetes. Nutr. Res. 2010, 30, 1-13. [CrossRef]

33. Lee, G.M.; Suh, D.H.; Jung, E.S.; Lee, C.H. Metabolomics Provides Quality Characterization of Commercial Gochujang (Fermented Pepper Paste). Molecules 2016, 21, 921. [CrossRef] [PubMed]

34. Chen, Y.; Gao, X.; Wei, Y.; Liu, Q.; Jiang, Y.; Zhao, L.; Ulaah, S. Isolation, purification and the anti-hypertensive effect of a novel angiotensin I-converting enzyme (ACE) inhibitory peptide from Ruditapes philippinarum fermented with Bacillus natto. Food Funct. 2018, 9, 5230-5237. [CrossRef] [PubMed]

35. Jemil, I.; Mora, L.; Nasri, R.; Abdelhedi, O.; Aristoy, M.C.; Hajji, M.; Nasri, M.; Toldrá, F. A peptidomic approach for the identification of antioxidant and ACE-inhibitory peptides in sardinelle protein hydrolysates fermented by Bacillus subtilis A26 and Bacillus amyloliquefaciens An6. Food Res. Int. 2016, 89, 347-358. [CrossRef] [PubMed]

36. Moayedi, A.; Mora, L.; Aristoy, M.C.; Safari, M.; Hashemi, M.; Toldrá, F. Peptidomic analysis of antioxidant and ACE-inhibitory peptides obtained from tomato waste proteins fermented using Bacillus subtilis. Food Chem. 2018, 250, 180-187. [CrossRef] 